\title{
PELAKSANAAN PERAN SERTA MASYARAKAT PADA PENGADAAN TANAH UNTUK KEPENTINGAN UMUM (Studi Kasus Pelebaran Jalan Di Kota Praya, Kabupaten Lombok Tengah)
}

\author{
Hery Zarkasih ${ }^{1}$ \\ Staf Pengajar Fakultas Hukum Universitas 45 Mataram \\ Email1: heryherbanza07@gmail.com \\ Mirza Amelia ${ }^{2}$ \\ Staf Pengajar Fakultas Hukum Universitas 45 Mataram \\ Email2: ameliaaoshy@gmail.com \\ DOI:https://doi.org/10.31764/jmk.v9i2.891
}

Received: Augst 25, 2018, Accepted: Sept 20, 2018 /Published: Oktober 30, 2018

\begin{abstract}
This article discusses the implementation of community participation in providing compensation for road widening in Praya City, Central Lombok Regency. The land acquisition process does not involve the community and is given active opportunities, so that the input and support for the implementation of land acquisition is not optimal. Another problem is the lack of public information on the process of land acquisition activities and the implementation of compensation. This research is a normative-empirical study, using a legislative, sociological, philosophical approach, and analyzed descriptively qualitatively. The results of the study, that the implementation of community participation in the provision of compensation for widening the road in the City of Praya has been carried out based on the provisions of Law No. 2 of 2011. In the perspective of justice raises differences of opinion based on which point of view assessing the justice side, in terms of substantive justice and / or procedural justice. Barriers to the implementation of community participation in Praya City are conflicts that occur between communities, but can be resolved by deliberation.
\end{abstract}

Keywords: community participation; compensation.

\section{ABSTRAK}

Artikel ini membahas tentang pelaksanaan peran serta masyarakat dalam pemberian ganti rugi pelebaran jalan di Kota Praya, Kabupaten Lombok Tengah. Proses pengadaan tanah tidak melibatkan masyarakat dan diberi kesempatan secara aktif, sehingga masukan dan dukungan penyelenggaraan pengadaan tanah tidak maksimal. Permasalahan lain, kurangnya informasi masyarakat terhadap proses kegiatan pengadaan tanah serta pelaksanaan pemberian ganti rugi. Penelitian ini merupakan penelitian normatif-empiris, menggunakan pendekatan perundangundangan, sosiologis, filosofis, dan di analisis secara deskriptif kualitatif. Hasil penelitian, bahwa penyelenggaraan peran serta masyarakat dalam 
pemberian ganti rugi pelebaran jalan di Kota Praya telah dilaksanakan berdasarkan ketentuan Undang-Undang Nomor 2 Tahun 2011. Pada perspektif keadilan menimbulkan perbedaan pendapat berdasarkan sudut pandang mana menilai sisi keadilan, dari sisi keadilan substantif dan/atau keadilan prosedural. Hambatan pelaksanaan peran serta masyarakat di Kota Praya adalah konflik yang terjadi antar masyarakat, akan tetapi dapat diselesaikan dengan musyawarah.

Kata kunci: peran serta masyarakat; ganti rugi.

\section{PENDAHULUAN}

Pembangunan untuk kepentingan umum membutuhkan tanah sebagai salah satu aspek penting pendukung keberhasilan pelaksanaannya, namun yang menjadi permasalahan adalah jumlah tanah yang dikuasai oleh negara terbatas. Berdasarkan keadaan tersebut maka mulai dilakukan pengadaan tanah oleh Pemerintah dengan menggunakan tanah perseorangan atau badan hukum yang telah dikuasai dengan suatu hak atas tanah guna memenuhi kebutuhan tanah bagi kegiatan pembangunan untuk kepentingan umum.

Pada perkembangannya pada saat ini, pengadaan tanah untuk kepentingan umum diatur dalam Undang-Undang Nomor 2 Tahun 2012 tentang Pengadaan Tanah Bagi Pembangunan Untuk Kepentingan Umum yang diundangkan pada tanggal 14 Januari 2012. Undang-Undang ini dilengkapi dengan Peraturan Presiden Nomor 71 Tahun 2012 tentang Penyelenggaraan Pengadaan Tanah Bagi Pembangunan Untuk Kepentingan Umum.

Pengaturan peran serta masyarakat dalam Undang-Undang Nomor 2 Tahun 2012 tentang Pengadaan Tanah Bagi Pembangunan Untuk Kepentingan Umum diatur dalam ketentuan Pasal 57 huruf a dan b, yang menyatakan bahwa masyarakat dapat berperan serta, antara lain :

a. memberikan masukan secara lisan atau tertulis mengenai Pengadaan Tanah; dan

b. memberikan dukungan dalam penyelenggaraan Pengadaan Tanah. 
Apabila masayarakat tidak dilibatkan dalam proses pengadaan tanah dan tidak diberi kesempatan untuk bertindak secara aktif, maka masyarakat tidak akan dapat memberikan masukan dan dukungan dalam penyelenggaraan Pengadaan Tanah. Peran serta masyarakat yang tidak maksimal juga akan mengakibatkan kurangnya informasi masyarakat terhadap proses kegiatan pengadaan tanah termasuk dalam pelaksanaan pemberian ganti rugi.

Pada umumnya terdapat beberapa kendala dalam pelaksanaan pemberian ganti rugi pengadaan tanah pada pelebaran jalan di Kota Praya, Kabupaten Lombok Tengah diantaranya adalah: ${ }^{1}$

1. Penilaian dari Lembaga Penilai (appraisal) yang dianggap tidak sesuai dengan harga pasar, sehingga terjadi permohonan dari masyarakat untuk dihitung kembali nilai tanah dan bangunan.

2. Adanya anggapan warga, bahwa terdapat perbedaan nilai ganti rugi yang diberikan antara warga yang satu dengan warga yang lainnya.

3. Adanya kecemburuan dari warga bahwa pemerintah akan mempermainkan warga dalam pemberian ganti rugi, karena penilaian dilakukan berdasarkan oleh lembaga penilai (appraisal) dengan menggunakan mekanisme tersendiri.

Berdasarkan hambatan di atas, maka peran serta masyarakat merupakan hal yang sangat penting untuk dilakukan secara maksimal dalam kegiatan pengadaan tanah di Indonesia khususnya pelebaran jalan di Kota Praya, Kabupaten Lombok Tengah. Pelaksanaan peran serta merupakan upaya yang dilakukan untuk mengatasi potensi terjadinya hambatan dalam kegiatan pengadaan tanah bagi pembagunan untuk kepentingan umum, karena pada akhirnya hasil kegiatan pengadaan tanah adalah untuk kepentingan seluruh lapisan masyarakat dengan menikmati manfaat ruang berupa manfaat ekonomi dan sosial.

\footnotetext{
${ }^{1}$ Hery Zarkasih, "Pelaksanaan Prinsip Keadilan dalam pemberian Ganti Rugi Pengadaan Tanah Untuk Kepentingan Umum (Studi Kasus Pelebaran Jalan Di Kota Praya, Kabupaten Lombok Tengah)", Tesis, Universitas Mataram, 2015, Hlm. 99.
} 


\section{METODOLOGI}

Penelitian ini dikategorikan sebagai penelitian hukum normatif-empiris, yaitu penelitian yang dilakukan dengan mengkaji ketentuan perundangundangan (in abstracto) serta melihat fakta-fakta hukum yang terjadi di lapangan (in concreto) ${ }^{2}$ yang berkaitan dengan pemberian ganti rugi pengadaan tanah untuk kepentingan umum. Menggunakan beberapa pendekatan, yaitu pendekatan perundang-undangan (stute approach). Pendekatan sosiologis (sosiological aproach), dan pendekatan analitis (analytical approach). Pendekatan ini bertujuan untuk menganalisis pengertian hukum, asas hukum, kaidah hukum, sistem hukum, dan berbagai konsep yuridis. ${ }^{3}$

\section{PEMBAHASAN}

\section{A. Pelaksanaan Peran Serta Masyarakat dalam Pemberian Ganti Rugi Pelebaran Jalan di Kota Praya}

Pemerintah menyelenggarakan pembangunan dalam rangka mewujudkan masyarakat yang adil, makmur, dan sejahtera berdasarkan Pancasila dan Undang-Undang Dasar Negara Republik Indonesia Tahun 1945. Salah satu upaya pembangunan dalam kerangka pembangunan nasional yang diselenggarakan pemerintah pada saat ini adalah dengan menyelenggarakan pengadaan tanah untuk kepentingan umum. Penyelenggaraan pengadaan tanah untuk kepentingan umum dilaksanakan berdasarkan asas-asas dalam ketentuan Pasal 2 UndangUndang Nomor 2 Tahun 2012 tentang Pengadaan Tanah Bagi Pembangunan Untuk Kepentingan Umum, yaitu:

a. Asas kemanusiaan adalah Pengadaan Tanah harus memberikan pelindungan serta penghormatan terhadap hak asasi manusia,

2 Sudikno Mertokusumo, Penemuan Hukum, Liberty, Yogyakarta, 2004, Hal. 29.

${ }^{3}$ Mukti Fajar MD \& Yulianto Achmad, Dualisme Penelitian Hukum Normatif dan Empiris, Cetakan 1, Pustaka Pelajar, Yogyakarta, 2010, Hlm.157-158 
harkat, dan martabat setiap warga negara dan penduduk Indonesia secara proporsional.

b. Asas keadilan adalah memberikan jaminan penggantian yang layak kepada pihak yang berhak dalam proses Pengadaan Tanah sehingga mendapatkan kesempatan untuk dapat melangsungkan kehidupan yang lebih baik.

c. Asas kemanfaatan adalah hasil Pengadaan Tanah mampu memberikan manfaat secara luas bagi kepentingan masyarakat, bangsa, dan negara.

d. Asas kepastian adalah memberikan kepastian hukum tersedianya tanah dalam proses Pengadaan Tanah untuk pembangunan dan memberikan jaminan kepada Pihak yang Berhak untuk mendapatkan Ganti Kerugian yang layak.

e. Asas keterbukaan adalah bahwa Pengadaan Tanah untuk pembangunan dilaksanakan dengan memberikan akses kepada masyarakat untuk mendapatkan informasi yang berkaitan dengan Pengadaan Tanah.

f. Asas kesepakatan adalah bahwa proses Pengadaan Tanah dilakukan dengan musyawarah para pihak tanpa unsur paksaan untuk mendapatkan kesepakatan bersama.

g. Asas keikutsertaan adalah dukungan dalam penyelenggaraan Pengadaan Tanah melalui partisipasi masyarakat, baik secara langsung maupun tidak langsung, sejak perencanaan sampai dengan kegiatan pembangunan.

h. Asas kesejahteraan adalah bahwa Pengadaan Tanah untuk pembangunan dapat memberikan nilai tambah bagi kelangsungan kehidupan Pihak yang Berhak dan masyarakat secara luas.

i. Asas keberlanjutan adalah kegiatan pembangunan dapat berlangsung secara terus-menerus, berkesinambungan, untuk 
mencapai tujuan yang diharapkan.

j. Asas keselarasan adalah bahwa Pengadaan Tanah untuk pembangunan dapat seimbang dan sejalan dengan kepentingan masyarakat dan negara.

Pengadaan Tanah untuk Kepentingan Umum bertujuan menyediakan tanah bagi pelaksanaan pembangunan guna meningkatkan kesejahteraan dan kemakmuran bangsa, negara, dan masyarakat dengan tetap menjamin kepentingan hukum Pihak yang Berhak. termasuk dalam pengadaan tanah di Kota Praya Kabupaten Lombok Tengah.

Gambar.1

Lokasi pelebaran jalan di Kota Praya

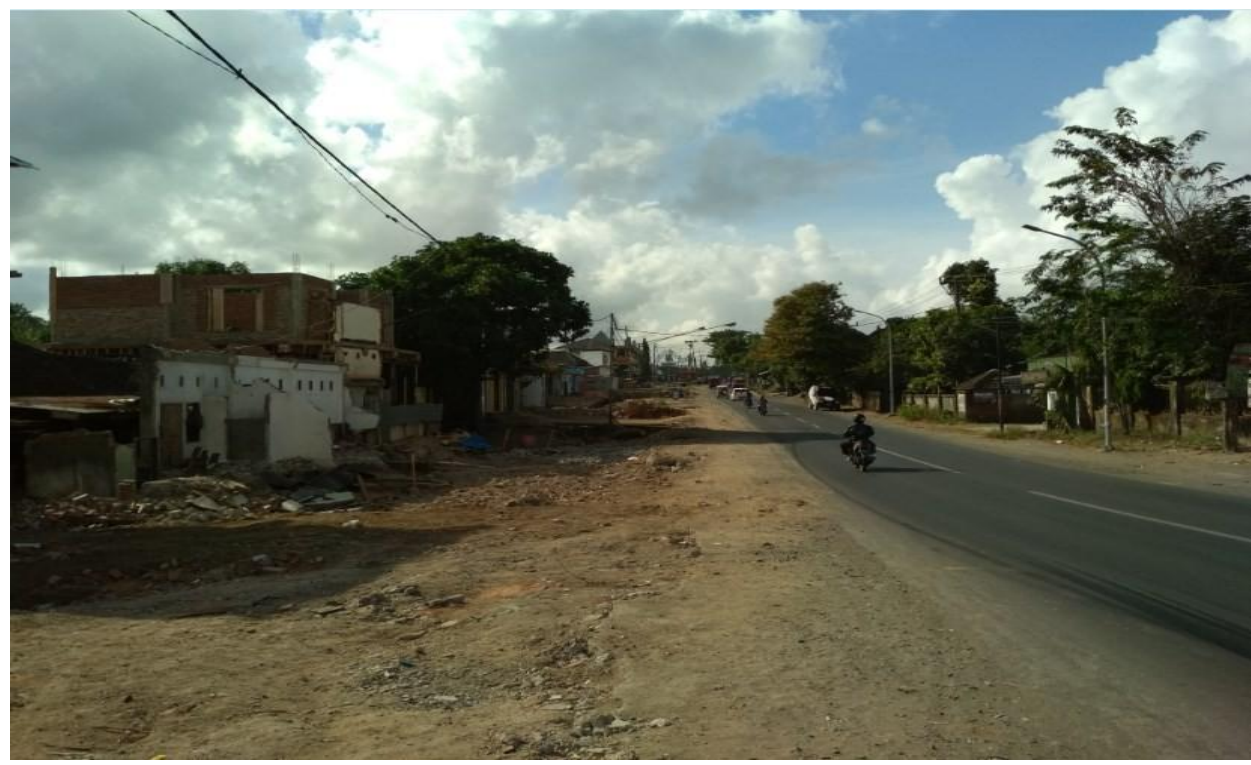

Penyelenggaraan pengadaan tanah tentunya harus melibatkan masyarakat dalam kegiatan tersebut. Peran serta masyarakat dalam Pemberian Ganti Rugi Pelebaran Jalan di Kota Praya telah dilaksanakan berdasarkan ketentuan Undang- Undang Nomor 2 Tahun 2011 tentang Pengadaan Tanah Bagi Pembangunan Untuk Kepentingan Umum yaitu dalam ketentuan Pasal 55, 56, dan 57 BAB VI tentang Hak, Kewajiban, dan Peran Serta Masyarakat. 


\section{B. Pelaksanaan Pemberian Ganti Rugi Pelebaran Jalan di Kota Praya Ditinjau dari Perspektif Keadilan}

Pelaksanaan pemberian ganti rugi pelebaran akan menimbulkan rasa keadilan dan ketidak adlian bagi masyarakat yang terkena pelebaran jalan termasuk di wilayah Kota Praya. Pengadaan Tanah berdasarkan kriteria umum yang ada harus tetap memperhatikan aspek keadilan dalam pemberian ganti kerugian kepada pihak yang berhak. Keadilan yang dimaksud sebagaimana yang dijelaskan dalam penjelasan umum Pasal 2 huruf b Undang-Undang Nomor 2 Tahun 2012 tentang Pengadaan Tanah Bagi Pembangunan untuk Kepentingan Umum adalah "memberikan jaminan penggantian yang layak kepada pihak yang berhak dalam proses pengadaan tanah sehingga mendapatkan kesempatan untuk dapat melangsungkan kehidupan yang lebih baik".

Beberapa pelaksanaan pemberian ganti rugi ditinjau dalam perspektif keadilan :

a. Menurut Bapak Mohammad Amir Ali Kepala Dinas Pekerjaan Umum dan Penataan Ruang Kabupaten Lombok Tengah pelaksanaan pemberian ganti rugi pengadaan tanah untuk kepentingan umum di Kota Praya pada tahun 2018 sudah adil karena di dalam pelaksanaannya pemerintah tidak mendapatkan hambatan. Penilaian besarnya ganti rugi dilakukan oleh Tim Appraisal. ${ }^{4}$

b. Menurut M. Rosikhan masyarakat Tiwu Galih, Karang Lebah Kota Praya: pemberian ganti rugi pelebaran jalan di Kota Praya belum adil karena posisi tanah saya berada di wilayah Kota Praya, sedangkan daerah yang lain harganya lebih tinggi. Mau tidak mau kita harus menerima karena merupakan program pemerintah. ${ }^{5}$

c. Menurut Mahali Idris masyarakat Tiwu Galih Kota Praya pemberian ganti rugi pelebaran jalan di Kota Praya sudah adil karena uang ini sudah diterima, ada sebagian di sebelah jembatan ini sudah di gali,

\footnotetext{
4 Wawancara dengan Bapak Mohammad Amir Ali Kepala Dinas Pekerjaan Umum dan Penataan Ruang Kabupaten Lombok Tengah Pada Tanggal 28 Juni 2018 Pukul 9.27 WITA.

5 Wawancara dengan Bapak M. Rosikhan masyarakat yang terkena pelebaran jalan di Kota Praya Kelurahan Tiwu Galih Kabupaten Lombok Tengah Pada Tanggal 2 Juli 2018 Pukul 10.30 WITA.
} 
namun belum ada sosialisasi tentang penambahan $1 \mathrm{~m} \cdot{ }^{6}$

d. Menurut Kahfi masyarakat Tiwu Galih, Karang Lebah Kota Praya pemberian ganti rugi pelebaran jalan di Kota Praya belum adil, karena masih ada peroses penambahan pelebaran jalan yang belum disosialisasikan. ${ }^{7}$

e. Menurut Harsono warga yang tinggal di Kota Praya Kelurahan Prapen yang terkena pelebaran jalan tahun 2014, menyatakan bahwa pemberian ganti rugi tidak adil karena cara pembagiannya yang berbeda-beda, ada yang dapat sedikit bangunannya besar, sebaliknya ada yang dapat banyak bangunannya kecil. "Ya, meski tidak adil, saya mau tidak mau tetap menerima karena proyek itu untuk kepentngan umum," kata Harsono. ${ }^{8}$

f. Keadilan sosial mengikuti hakikat Pancasila, yaitu perikemanusiaan. Keadilan sosial mengandung maksud bahwa di dalam kehidupan sosial harus ada perbuatan yang saling memanusiakan manusia. Mengutip pendapat Hyronimus Rhiti, keadilan sosial bukan berarti demi "keadilan sosial" maka martabat individu direndahkan atau dihancurkan. Keadilan sosial tetap memberikan penghargaan terhadap individu. Nilai keadilan tidak boleh ditawar-tawar dan harus diwujudkan ke dalam masyarakat tanpa harus mengorbankan kepentingan masyarakat lainnya. ${ }^{9}$ Jika dihubungkan dengan kegiatan pengadaan tanah, maka setiap kegiatan pengadaan tanah tidak boleh mengorbankan kepentingan masyarakat lainnya, akan tetapi jika melihat pelaksanaan pengadaan tanah termasuk pelebaran jalan di Kota Praya, pasti akan menyebabkan beberapa masyarakat merasa tidak adil, hal ini disebabkan karena nilai ekonomis tanah yang berada di pinggir jalan akan berbeda dengan yang tidak berada di pinggir jalan, sehingga apabila seluruh tanah beserta bangunan warga terkena pelebaran jalan maka warga tersebut harus mencari lokasi tempat tinggal baru yang nilai ekonominya belum tentu sama dengan tempat sebelumya.

g. John Rawls mensyaratkan dua prinsip keadilan sosial, yakni equal liberty (prinsip kebebasan yang sama) dan equal opportunity (kesempatan yang sama). Equal liberty yakni setiap orang memiliki hak atas kebebasan individual (liberty) yang sama dengan hak orang

6 Wawancara dengan Bapak Mahali Idris masyarakat yang terkena pelebaran jalan di Kota Praya Kelurahan Tiwu Galih Kabupaten Lombok Tengah Pada Tanggal 3 Juli 2018 Pukul 09.00 WITA

7 Wawancara dengan Bapak Kahfi masyarakat yang terkena pelebaran jalan di Kota Praya Kelurahan Tiwu Galih Kabupaten Lombok Tengah Pada Tanggal 9 Juli 2018 Pukul 09.00 WITA.

8 Hery Zarkasih, Pelaksanaan Prinsip Keadilan Dalam Pemberian Ganti Rugi Pengadaan Tanah Untuk Kepentingan Umum (Studi Kasus Pelebaran Jalan Raya Di Kota Praya Kabupaten Lombok Tengah), Tesis. Magister Ilmu Hukum Universitas Mataram Tahun 2015. Halaman 83

9 Hyronimus Rhiti, 2011, Filsafat Hukum Edisi Lengkap (dari klasik sampai postmodernisme), Universitas Atma Jaya Yogyakarta, Yogyakarta. Hal 255

Volume 9 Nomor 2, Oktober 2018: (142-158) | Media Keadilan: Jurnal Ilmu Hukum 
lainnya. Equal opportunity yakni memberikan kesempatan yang sama bagi semua orang dengan persyaratan yang adil. ${ }^{10}$ John Rawls memberikan pandangan bahwa untuk mencapai suatu keadilan, diisyaratkan sekaligus adanya unsur keadilan yang substantif (justice) dan unsur keadilan prosedural (fairness). Keadilan substansial dimaknai sebagai keadilan yang secara riil diterima dan dirasakan oleh para pihak, sementara keadilan prosedural lebih berorientasi pada keadilan yang telah dirumuskan oleh hukum dalam bentuk hak dan kewajiban. ${ }^{11}$ Artinya bahwa, hukum akan menjadi adil apabila kedua macam

Keadilan yang dirumuskan oleh hukum dalam bentuk hak dan kewajiban harus mencerminkan keadilan yang diterima dan dirasakan oleh warga masyarakat yang mengalami pelebaran jalan. Keadilan yang dirumuskan oleh hukum diantaranya adalah:

a. Ketentuan Pasal 1 angka 2 Undang-Undang Nomor 2 Tahun 2012 tentang pengadaan tanah untuk kepentingan umum disebutkan bahwa "pengadaan tanah adalah kegiatan menyediakan tanah dengan cara memberi ganti kerugian yang layak dan adil kepada pihak yang berhak." Adil yang dimaksud dalam hal ini sebagaimana telah diatur dalam ketentuan Pasal 2 Undang-Undang Nomor 2 Tahun 2012 tentang Pengadaan Tanah Bagi Pembangunan Untuk Kepentingan Umum. Artinya, memberikan jaminan penggantian yang layak kepada pihak yang berhak dalam proses pengadaan tanah sehingga mendapatkan kesempatan untuk dapat melangsungkan kehidupan yang lebih baik.

b. Ketentuan Pasal 3 Undang-Undang Nomor 39 Tahun 1999 tentang Hak Asasi Manusia menegaskan bahwa keadilan merupakan hak setiap warga negara yang harus dijamin dan dilindungi oleh negara. Hal ini menegaskan bahwa keadilan merupakan hak bagi setiap pemegang hak atas tanah yang memperoleh ganti rugi pengadaan 
tanah untuk kepentingan umum.

Pelaksanaan pemberian ganti rugi pelebaran jalan di Kota Praya jika ditinjau dalam perspektif keadilan akan menimbulkan perbedaan pendapat antara pemerintah masyarakat dan para ahli, karena masingmasing memiliki sudut pandang. Menurut penulis kegiatan pengadaan tanah untuk kepentingan umum yang dilakukan harus tetap memperhatikan aspek keadilan bagi semua pihak yang terlibat dalam kegiatan pengadaan tanah, termasuk pandangan keadilan seperti yang diuraikan oleh John Rawls di atas, dengan memperhatikan 2 (dua) aspek yaitu keadilan yang substantif dan prosedural.

\section{Faktor-Faktor Hambatan Pelaksanaan Peran Serta Masyarakat dalam} Pemberian Ganti Rugi Pelebaran Jalan di Kota Praya dan Upaya Mengatasinya

Pelaksanaan Ganti Rugi pengadaan tanah untuk kepentingan umum seringkali mengalami hambatan-hambatan, termasuk dalam kegiatan pengadaan tanah di dareah Kabupaten Lombok Tengah. Hambatan dan kendala yang datang dari sisi masyarakat adalah kemajemukan masyarakat itu sendiri, baik dari segi tingkat pendidikan, tingkat penghasilan, suku bangsa, dan lain sebagainya. Selain itu adanya 'image' atau anggapan masyarakat yang negatif terhadap Pemerintah. Anggapan yang negatif terhadap pemerintah tersebut muncul karena beberapa sebab, di antaranya adalah: ${ }^{12}$

a. Adanya anggapan bahwa kebijakan pemerintah mengenai pengadaan tanah selama ini belum sepenuhnya berorientasi kepada masyarakat, sehingga masyarakat merasa tidak perlu terlibat langsung dan menyampaikan aspirasinya;

b. Pelibatan masyarakat yang belum efektif secara langsung maupun tidak langsung, sejak perencanaan sampai dengan kegiatan pembangunan. Hal inilah yang menyebabkan masyarakat tidak mengerti apa yang menjadi hak dan kewajibannya dalam kegiatan

12 Ibid. hal. 95. 
pengadaan tanah;

c. Belum terbukanya Pemerintah dalam proses penyelenggaraan Pengadaan tanah, dan adanya anggapan bahwa masyarakat hanya dijadikan obyek pembangunan saja;

d. Penyelenggaraan pengadaan tanah dianggap belum dilakukan secara transparan dari tahap persiapan, perencanaan, pelaksanaan dan penyerahan hasil;

e. Penilaian ganti rugi didasarkan pada hasil penilaian dari Lembaga Penilai (Appraisal), yang menilai besarnya ganti rugi dengan mekanisme tersendiri. Sehingga menimbulkan kecurigaan bahwa pemerintah akan mempermainkan masyarakat.

f. Dengan adanya pengaturan tentang penitipan di pengadilan (konsinyasi), menimbulkan anggapan bahwa masyarakat hanya dihadapkan pada 1 (satu) pilihan, yaitu apabila tidak menerima/keberatan dengan nilai ganti rugi, maka uang ganti rugi akan dititipkan di pengadilan setempat.

Menurut Ibu Nurul Haerani Kasi Perencanaan Teknis Sumber Daya Air Dinas Pekerjaan Umum dan Penataan Ruang Kabupaten Lombok Tengah. Beberapa hambatan dalam pelaksanaan ganti rugi pengadaan tanah di Kabupaten Lombok Tengah Khusunya di daerah Mujur diantaranya: ${ }^{13}$

a Masyarakat meminta kepastian biaya relokasi (ganti rugi) sedangkan pihak PU tidak bisa memberikan jawaban karna pihak PU tidak berwenang dalam memberikan jawaban yang pasti tentang hal tersebut

b. Pihak PU tidak mengetahui dan tidak memiliki data yang lengkap tentang tanah-tanah yang terkena kegiatan pengadaan tanah.

c. Pembangunan Dam Mujur sudah direncanakan dalam waktu yang cukup lama, tetapi pemerintah belum bisa menyelesaikan pembangunan Dam Mujur karena pembebasan lahan yang tidak bisa terselesaikan khususnya di desa Kelebuh.

d. Karena masyarakat sudah terlalu lama dijanjikan untuk dilaksanakan pembangunan dam mujur, sehingga masyarakat jenuh dengan janji- janji yang ada.

Hambatan-hambatan dalam peran serta masyarakat di Kota Praya

13 Novita Listyaningrum \& Hery Zarkasih, Pelaksanaan Ganti Rugi Pengadaan Tanah Untuk Kepentingan Umum (Studi Kasus Pembangunan Dam Mujur di Kabupaten Lombok Tengah), Jurnal Media Keadilan, Halaman 313 
diantaranya dapat dilihat dari hasil musyawarah pada Tahun 2014 di

Kelurahan Prapen dan Panjisari Kabupaten Lombok Tengah dalam pada Tabel 1.

Tabel 1:

Hasil Musyawarah

\begin{tabular}{|c|c|c|c|}
\hline No & Pertemuan & $\begin{array}{l}\text { Jumlah Yang } \\
\text { Tidak Setuju }\end{array}$ & Alasan Tidak Menerima Ganti Rugi \\
\hline 1 & $\begin{array}{l}\text { Kelurahan Prapen } \\
\text { Musyawarah ke-I Tanggal } \\
\text { 29 Januari } 2014\end{array}$ & 38 & $\begin{array}{l}\text { a. Minta tanah diukur ulang } \\
\text { b. Tidak setuju dengan harga tanah } \\
\text { c. minta bngunannya diukur ulang } \\
\text { dan harga bangunan } \\
\text { d. minta bangunannya dipisahkan } \\
\text { e. tidak setuju harga tanaman }\end{array}$ \\
\hline 2 & $\begin{array}{l}\text { Kelurahan Prapen } \\
\text { Musyawarah ke-II Tanggal } \\
\text { 17 Februari } 2014\end{array}$ & 21 & $\begin{array}{l}\text { a. minta diukur ulang tanah karena } \\
\text { tidak setuju harga } \\
\text { b. Minta ukur ulang bangunan } \\
\text { c. belum setuju harga bangunan } \\
\text { d. minta bangunan dipisahkan } \\
\text { karena dimiliki } 2 \text { (dua) orang } \\
\text { e. adanya sengketa dengan pemilik } \\
\text { lama }\end{array}$ \\
\hline$\beta$ & \begin{tabular}{|l} 
Kelurahan Prapen \\
Musyawarah ke-III \\
Tanggal 4 Maret 2014
\end{tabular} & 1 & Ada sengketa dengan pemilik lama \\
\hline 4 & $\begin{array}{l}\text { Kelurahan Panjisari } \\
\text { Musyawarah ke-I Tanggal } \\
12 \text { februari } 2014\end{array}$ & 13 & $\begin{array}{l}\text { a. Minta tanah diukur ulang } \\
\text { b. Tidak setuju dengan harga tanah } \\
\text { c. minta bngunannya diukurulang } \\
\text { dan harga bangunan } \\
\text { d. minta bangunannya dipisahkan, } \\
\text { karena ada } 3 \text { pemilik } \\
\text { e. tidak setuju harga tanaman } \\
\text { f. minta tanah diukur ulangkarena } \\
\text { ada kaitannya dengan pemilik } \\
\text { lama } \\
\text { g. Ada gang ditimur masjid, minta } \\
\text { diukur juga } \\
\text { h. Minta diukur ulang karena ada } \\
\text { pondasi yang belum dihitung }\end{array}$ \\
\hline 5 & $\begin{array}{l}\text { Kelurahan Panjisari } \\
\text { Musyawarah ke-II Tanggal } \\
12 \text { Maret } 2014\end{array}$ & - & 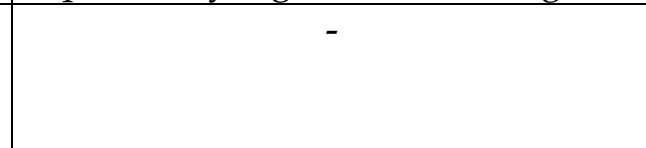 \\
\hline
\end{tabular}

Sumber: Berita acara hasil musyawarah yang telah diolah 
Berdasarkan Tabel 1 di atas, hambatan yang terjadi yaitu terdapat penolakan oleh masyarakat dalam kegiatan musyawarah. Beberapa alasan warga menolak hasil musyawarah ganti rugi disebabkan karena harga tanah dan bangunan yang tidak sesuai dengan yang diinginkan, sehingga mereka meminta untuk diukur ulang baik dari segi bangunan dan tanaman. Setelah dilaksanakan musyawarah tahap selanjutnya, pada akhirnya semua masyarakat setuju terhadap besarnya ganti rugi yang diberikan kepada masyarakat.

Menurut Bapak Mohammad Amir Ali Kepala Dinas Pekerjaan Umum dan Penataan Ruang Kabupaten Lombok Tengah, dalam pelaksanaan pengadaan tanah untuk kepentingan umum pada Tahun 2018 ini, pemerintah belum menemukan hambatan yang terjadi antara pemerintah dengan masyaraka. Hambatan yang terjadi dalam pelaksanaan peran serta masyarakat dalam pemberian ganti rugi pelebaran jalan di Kota Praya Kabupaten Lombok Tengah adalah konflik-konflik yang terjadi antara masyarakat dengan masyarakat, hal ini yang mengakibatkan proses pengadaan tanah menjadi terhambat. ${ }^{14}$ Upaya-upaya yang dilakukan untuk mengatasi hal tersebut adalah dengan melakukan musyawarah antara para pihak yang berkonflik. Pemerintah selalu memfasilitasi masyarakat untuk melakukan musyawarah sehingga tercapai kesepakatan untuk menyelesaiakan permasalahan yang ada.

Upaya yang harus dilakukan pemerintah untuk mengatasi hambatan- hambatan pengadaan tanah untuk kepentingan umum di Kota Praya adalah: ${ }^{15}$

a. Pemerintah harus selalu mengupayakan musyawarah untuk mufakat dalam menghadapi permasalahan-permasalahan

14 Ibid

15 Pasal 55, 56, dan 57 Undang-Undang Nomor 2 Tahun 2012 tentang Pengadaan Tanah Untuk Kepentingan Umum. 
pengadaan tanah yang ada di Kota Praya Kabupaten Lombok Tengah seperti yang telah diamanatkan dalam bunyi sila keempat pancasila yang bunyinya kerakyatan yang dipimpin oleh hikmat kebijaksanaan dalam permusyawaratan dan perwakilan. Musyawarah dilakkan dengan tujuan menciptakan win win solution.

b. Melibatkan masyarakat dalam kegiatan pengadaan tanah, baik pada tahapan persiapan sampai dengan tahapan pelaksanaan seperti yang telah diatur dalam ketentuan Pasal 55, 56, dan 57 Undang-Undang Nomor 2 Tahun 2012 tentang Pengadaan Tanah Untuk Kepentingan Umum, sebagai berikut:

1) Pasal 55 Undang-Undang Nomor 2 Tahun 2012 menyebutkan bahwa dalam penyelenggaraan Pengadaan Tanah, Pihak yang Berhak mempunyai hak:

(a) Mengetahui rencana penyelenggaraan Pengadaan Tanah; dan

(b) Memperoleh informasi mengenai Pengadaan Tanah.

2) Pasal 56 Undang-Undang Nomor 2 Tahun 2012 menyebutkan bahwa dalam penyelenggaraan Pengadaan Tanah untuk Kepentingan Umum, setiap orang wajib mematuhi ketentuan Pengadaan Tanah bagi Pembangunan untuk Kepentingan Umum.

3) Pasal 57 Undang-Undang Nomor 2 Tahun 2012 menyebutkan bahwa dalam penyelenggaraan Pengadaan Tanah untuk Kepentingan Umum, masyarakat dapat berperan serta, antara lain:

(a) Memberikan masukan secara lisan atau tertulis mengenai Pengadaan Tanah; dan

(b) Memberikan dukungan dalam penyelenggaraan Pengadaan Tanah

c. Agar suatu program pembangunan berjalan sesuai dengan kebutuhan masyarakat, harus ada jaminan bahwa partisipasi masyarakat terlibat didalamnya. Maka untuk menjamin hal itu terjadi harus ada terciptanya: ${ }^{16}$

1) Politik Will dari pemerintah daerah untuk membuka ruang dan arena bagi masyarakat untuk berpartisipasi. Karena selama ini atau selama orde lama dikondisikan dengan menerima apa yang diperintahkan oleh pemerintah pusat, dan tidak dibiasakan untuk melakukan program secara partisipatif.

2) Adanya jaminan atau garansi bagi orang yang berpatisipasi. Bahwa partisipasi merupakan syarat dari setiap program

16 Dadang Juliantara, Peningkatan Kapasitas Pemerintah Daerah dalam Pelayanan Publik, Pembaruan, Yogyakarta, 2005 hal. 37-38. 
pembangunan, otomatis harus melibatkan stakeholders.

3) Masyarakat sebagai stakeholder harus belajar juga untuk berpartisipasi, apabila ruang dan arena sudah disediakan dan jaminan sudah diberikan maka masyarakat tidak akan takut lagi untuk mengeluarkan aspirasi dan berpatisipasi dalam proses pembangunan.

Peran serta masyarakat perlu dilaksanakan dengan maksimal. Pelaksanaan peran serta masyarakat harus dilakukan dalam setiap tahapan pengadaan tanah untuk kepentingan umum agar masyarakat mengetahui apa yang menjadi hak dan kewajibannya. Hal ini dilakukan untuk mengatasi potensi terjadinya hambatan-hambatan dalam pengadaan tanah untuk kepentingan umum di Kota Praya Kabupaten Lombok Tengah.

\section{SIMPULAN}

Penyelenggaraan pengadaan tanah untuk kepentingan umum, melibatkan masyarakat, baik dalam dalam pemberian ganti rugi dan prosesnya. Pelaksanaan pemberian ganti rugi pelebaran jalan di Kota Praya pada perspektif keadilan, menimbulkan perbedaan pendapat antara pemerintah, masyarakat, dan para ahli. Masing-masing memiliki sudut pandang yang beragam. Aspek keadilan bagi semua pihak yang terlibat dalam kegiatan pengadaan tanah, dengan memperhatikan dua aspek, yaitu keadilan yang substantif dan prosedural. Artinya keadilan yang dimaknai sebagai keadilan yang secara riil diterima dan dirasakan oleh para pihak, serta berorientasi pada keadilan yang telah dirumuskan oleh hukum dalam bentuk hak dan kewajiban tanpa mengorbankan keadilan bagi sebagian individu masyarakat. Pelaksanaan peran serta masyarakat dalam pemberian ganti rugi pelebaran jalan di Kota Praya Kabupaten Lombok Tengah adalah konflik-konflik yang terjadi antara masyarakat dengan masyarakat. Akibatnya, proses pengadaan tanah menjadi terhambat. Upaya-upaya yang dilakukan adalah melakukan musyawarah 
antara para pihak yang berkonflik. Difasilitasi oleh pemerintah sehingga tercapai kesepakatan untuk menyelesaiakan permasalahan yang ada.

\section{DAFTAR PUSTAKA}

\section{Buku}

Bambang Sunggono, 2003, Metodologi Penelitian Hukum, Cetakan 5 PT Raja Grafindo Persada, Edisi II edI, Jakarta.

Bernard L. Tanya, Yoan N. Simanjuntak et. al., 2010, Teori Hukum, Cet. Ketiga, Genta Publishing, Yogyakarta.

Hyronimus Rhiti, 2011, Filsafat Hukum Edisi Lengkap (dari klasik sampai postmodernisme), Universitas Atma Jaya Yogyakarta, Yogyakarta.

John Rawls, 2006, A Theory of Justice, Harvard University Press Cambridge, Massachusetts. Diterjemahkan U.

Lili Rasjidi, Ira Tania Rasjidi, 2002, Pengantar Filsafat Hukum, Mandar Maju, Bandung.

Mhd Siddiq, 2003, Perkembangan Pemikiran Dalam Ilmu Hukum, Pradnya Paramita, Jakarta.

Mukti Fajar MD \& Yulianto Achmad, 2010, Dualisme Penelitian Hukum Normatif dan Empiris, Cetakan 1, Pustaka Pelajar,Yogyakarta.

Munir Fuady, 2010, Dinamika Teori Hukum, Ghalia Indonesia, Jakarta.

Rifyal Ka'bah, 2005, Pedoman Perilaku Hakim (Code of Conduct), Kode Etik, dan Makalah Berkaitan, Mahkamah Agung RI, Jakarta.

Soerjono Soekanto, 2010, Pengantar Penelitian Hukum, Penerbit Universitas Indonesia Jakarta.

Sudikno Mertokusumo, 2004, Penemuan Hukum, Liberty, Yogyakarta.

Hery Zarkasih, 2015. Pelaksanaan Prinsip Keadilan Dalam pemberian Ganti Rugi Pengadaan Tanah Untuk Kepentingan Umum (Studi Kasus Pelebaran Jalan Di Kota Praya, Kabupaten Lombok Tengah) Tesis, Universitas Mataram. 


\section{Peraturan Perundang-Undangan}

Indonesia. Undang-Undang Dasar Negara Republik Indonesia Tahun 1945; Indonesia. Undang-Undang Nomor 5 Tahun 1960 Tentang Peraturan Dasar Pokok-Pokok Agraria;

Indonesia. Undang-Undang Nomor 20 Tahun 1961 Tentang Pencabutan Hak Atas Tanah dan Benda-benda Yang Ada Diatasnya

Undang-Undang Nomor 2 Tahun 2012 Tentang Pengadaan Tanah Bagi Pembangunan Untuk Kepentingan Umum;

Peraturan Pemerintah Nomor 40 Tahun 1996 Tentang Hak Guna Usaha, Hak Guna Bangunan, dan Hak Pakai Atas Tanah;

Peraturan Pemerintah Nomor 24 Tahun 1997 tentang pendaftaran Tanah; Peraturan Presiden Nomor 71 Tahun 2012 tentang penyelenggaraan Pengadaan

Tanah Untuk Kepentingan Umum; dan

Perkaban Nomor 5 Tahun 2012 tentang Petunjuk Teknis Pelaksanaan Pengadaan Tanah. 